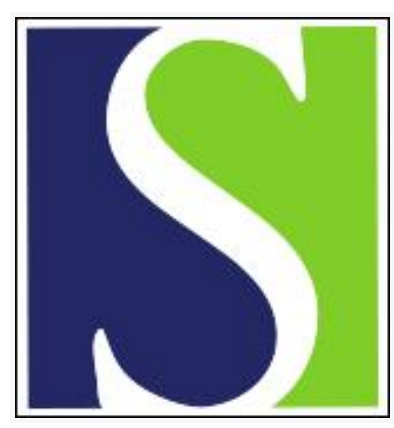

Scand J Work Environ Health 1995;21(5):325-334

https://doi.org/10.5271/sjweh.46

Issue date: Oct 1995

Reproductive disorders due to chemical exposure among hairdressers

by Kersemaekers WM, Roeleveld N, Zielhuis GA

The following articles refer to this text: 2002;28(1):33-41;

2013;39(3):302-309

Key terms: occupation; reproduction; review

This article in PubMed: www.ncbi.nlm.nih.gov/pubmed/8571088

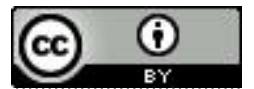




\title{
Reproductive disorders due to chemical exposure among hairdressers
}

\author{
Wendy M Kersemaekers, MSc, ${ }^{1}$ Nel Roeleveld, PhD, ${ }^{1}$ Gerhard A Zielhuis, PhD
}

\begin{abstract}
Kersemaekers WM, Roeleveld N, Zielhuis GA. Reproductive disorders due to chemical exposure among hairdressers. Scand J Work Environ Health 1995;21:325-34.

The evidence for reproductive disorders due to chemical exposure among hairdressers was evaluated. To this end, a literature study was conducted on Medline for the years 1985-1993. Reproductive disorders in humans were described for solvents such as ethanol and dichloromethane found mainly in hair sprays. Reproductive effects of several dye formulations, ethylene glycol ethers, nitrosamines, formaldehyde, hexachlorophene, and phthalic esters cannot be excluded, but few human data on low concentrations of these agents were available. Associations with menstrual disorders and spontaneous abortions were found in epidemiologic studies focused on hairdressers. Other studies showed inconsistent results, probably due to methodological shortcornings (misclassification of exposure, small sample sizes). It is concluded that there is little evidence for reproductive disorders among hairdressers to date. Limited availability of human data and unknown effects of chemical mixtures call for future research focused on human reproductive risks among hairdressers with emphasis on exposure assessment in the hairdressing salon.
\end{abstract}

Key terms occupation, reproduction, review.

Hairdressers are exposed to a variety of chemical agents in their use of several hair products such as shampoos, permanent wave solutions, hair dyes, and hair sprays. Several studies have been carried out on the potential adverse health effects of these chemical exposures $(1,2)$. Contact dermatitis and occupational asthma are major health problems for hairdressers $(1,3)$. Recently, the International Agency for Research on Cancer (IARC) evaluated human and animal studies on the carcinogenicity of hair dyes and concluded that the occupation of hairdresser entails exposures that are probably carcinogenic (4). Studies on reproductive disorders among hairdressers are scarce. However, reproductive disorders have been associated with exposure to solvents and other chemicals in various other occupations (5-8). Therefore, adverse effects of occupational exposure on the reproduction of hairdressers can be expected.

As hairdressers constitute a major occupational group of female workers with chemical exposures at childbearing age, it is important to know more about their risk for reproductive disorders such as infertility and subfertility, reproductive loss, congenital malformations, childhood cancers, and developmental disorders in offspring. The objective of the present review is to weigh the evi- dence of increased risk for reproductive disorders among hairdressers and to determine which activities, products, and agents are most likely to cause these effects. To this end, the literature on reproductive disorders in hairdressers and the reproductive effects of agents used by hairdressers was extensively evaluated.

\section{Methods}

To find epidemiologic studies on hairdressers and to determine which chemicals are used in hair products, an online computer search was conducted on Medline for the years 1985-1993 with the key words hairdressers, hair products, hair dyes, hair preparations, and hairdressing salons. Additional information about the ingredients of hair products was found in several reports on occupational exposure among hairdressers $(4,9-11)$ and gathered by verbal communication with manufacturers of hair products in The Netherlands.

As hairdressers make use of a wide range of products and as several thousands of chemicals are used in the composition of these products, it is impossible to describe the possible adverse effects of all these chemicals

1 Department of Medical Informatics, Epidemiology and Statistics, University of Nijmegen, The Netherlands.

Reprint requests to: Ms WM Kersemaekers, Department of Medical Informatics, Epidemiology and Statistics, University of Nijmegen, PO Box 9101, NL-6500 HB Nijmegen, The Netherlands. 
on reproduction. Therefore, a selection was made of widely used agents for which reproductive effects were described in several review books $(4,6,12,13)$. A subsequent online literature search was conducted on Medline for the years 1985-1993 with the selected agents and the term "reproduction," including menstrual disorders, infertility and subfertility, spontaneous abortions, stillbirths, congenital malformations, childhood cancers, and developmental disorders as key words. Additional papers were traced through references listed in the articles and books found.

As this review aims at an evaluation from an occupational health point of view instead of a complete toxicologic evaluation of each agent separately, attention was focused on human (mainly epidemiologic) studies. Experimental animal studies were evaluated when no or limited human data were available. Furthermore, the concentration of agents in hair products, frequency of use of these products in a hairdressing salon, and absorption routes were taken into account. However, the information on these issues was incomplete for most agents.

\section{Reproductive effects by exposure and task}

\section{Hair washing}

Shampoos are the products most often applied to hair. Laurylether sulfates are used as detergents in Europe and may be contaminated with nitrosamines (4). Because these agents occur in other products as well, information on possible reproductive effects is given under the heading "other exposures." Selenium sulfide has been used extensively as an antidandruff agent, but now its use is regulated in some countries (4). There were insufficient data with which to evaluate the reproductive effects of selenium exposure on humans (13). In animal experiments selenium has produced loss of fertility and congenital defects and is considered embryotoxic and teratogenic in relatively large doses $(6,12,13)$.

\section{Hair bleaching}

All of the bleaching methods currently in use are oxidation processes. Ammonium persulfate is often used in the formulations of bleaching powders that are mixed with hydrogen peroxide (about 10\%) just before application. Bleaching formulations are available in the form of solutions and emulsions, creams, shampoos, powders, pastes, and oils $(1,4)$.

No studies were found on the reproductive effects of hydrogen peroxide on humans. Schardein (6) reported one animal study which did not find a reproductive effect of hydrogen peroxide.

\section{Hair dyeing}

Hair dyes are found in the form of liquids, creams, gels, shampoos and powders, color rinses, foam tints, and emulsions. Aqueous solutions were recently replaced by alcoholic dyes (15- 20\% alcohol). Foam tints are dispensed as a foam from an aerosol can. Concentrated solutions can be obtained by using co-solvents (eg, alcohols and ethylene glycol ethers) and vehicles (eg, benzyl alcohol). The coloring lotion contains $0.1-5 \%$ dye and generally less than $1 \%$ of any individual dyestuff (4). The method of application may affect exposure. Permanent cream dyes, for example, are commonly applied with a brush, whereas other dyes are more often worked into the hair by hand (4). Cutaneous absorption of hair dyes by experimental animals and human subjects has been described in several studies and is suggested to be the major route of entry of the chemical into the biological system (14). Babish et al (15) found a significantly higher frequency of urinary mutagens among cosmetologists than among dental hygienists ( 35 versus $24 \%$ ), suggesting systemic absorption of hair dyes. Marzulli et al (16) reported skin penetration of some dyes in humans, monkeys and swine after application to uncovered skin and removal after $24 \mathrm{~h}$. The estimated skin penetrations were 2,4-toluenediamine (38\%), 2-nitro-p-phenylenediamine $(24 \%)$, and 2,4 -diaminoanisole $(4,3 \%)$. They also reported another study in which it appeared that washing the hair $40 \mathrm{~min}$ after application reduced the amount of skin penetration of 2,5-diaminotoluene to $0.2 \%$. Scalp penetration by several semipermanent and oxidative hair dyes was reported not to exceed $1 \%$ of the applied dose (17). To reduce dermal exposure, many hairdressers use protective gloves (4). A study on the potential exposure to para-phenylenediamine by inhalation in hairdressing salons, as measured by air sampling, concluded that no detectable exposure to para-phenylenediamine was apparent (18).

The possible adverse reproductive effects of alcohol and ethylene glycol ethers in hair dyes have been discussed under the heading Hair Styling. Maternal use of hair coloring products in the year prior to the child's birth appeared to be associated with Wilm's tumor in offspring in a pair-matched case-referent study among 88 cases and 88 referents in the United States [odds ratio (OR) 3.6, 95\% confidence interval $(95 \% \mathrm{CI}) 1.4-10.2]$ (19). In another matched case-referent study, with 104 cases and 101 referents (random-digit dialing), maternal use of hair dyes was found to be related to the risk of neuroblastoma (OR 3.0, 90\% CI 1.64-5.48) (20). Exposure to hair dyes also appeared to be related to an elevated risk of mental retardation in offspring in The Netherlands (OR 3.7, 90\% CI 1.1-16.7), but no information was available on the level of exposures or the specific substances involved (21). This study has been described more extensively under the heading Reproduc- 
tive Effects by Occupation. Several dye formulations were recently evaluated by IARC for cancer and other potential adverse effects, including reproductive toxicity (4), but no human data were available with regard to the reproductive effects of occupational exposure to hair dyes. Studies with experimental animals have shown inconsistent results concerning the teratogenicity of several dye formulations. For mice, evidence was found for the teratogenicity of 2,5-diaminotoluene (22), 2-nitro1,4-aminobenzene, 4-nitro-1,2-diaminobenzene, 4-nitroo-phenylenediamine, and 2-nitro-p-phenylenediamine (23). No teratogenic effects were found for animals after exposure to CI Acid Orange, HC Blue no 1, HC Blue no 2, HC Red no 3, HC Yellow no 4, 2-amino-4-nitrophenol, or 2-amino-5-nitrophenol (24-26). However, IARC noted that the concentrations used in these studies were very low and unlikely to have been toxic (4). Mutagenicity and, in some cases, genotoxicity was also reported for other hair dye substances such as hydroquinone (27), pyrogallol $(28)$, and aminophenols $(29,30)$ in various test systems. However, the interpretation with regard to human carcinogenic and reproductive risks is difficult. For lead acetate, there is no human evidence on teratogenicity, but it may be teratogenic in animals (31). Studies with women occupationally exposed to very high lead levels have shown an increased risk of abortion and stillbirth. However, there is no evidence for reproductive disorders from current lead exposure levels in hair dyes (31). Moreover, metal salts are rarely used in the hairdressing trade nowadays (32).

\section{Permanent waving}

Hydrogen peroxide $(0.5-3.0 \%)$ is used as an oxidizing agent in most parts of the world (4). As described under Bleaching, no reproductive effects of hydrogen peroxide were reported in the literature. Aerosol foam neutralizers are becoming increasingly popular in permanent wave solutions. A survey of exposures of hairdressers during permanent waving in the United Kingdom in 1992 showed ethanol at $2-30 \mathrm{mg} \cdot \mathrm{m}^{-3}$ (4). The reproductive effects of ethanol have been described under Hair Styling.

\section{Hair styling}

Hair-styling products are mainly setting lotions and hair sprays. Newer products are wet gels and hair waxes (4). Hair styling products are frequently used in hairdressing salons (9). Setting lotions are used in the form of diluted alcoholic solutions, gels, aerosol sprays, and aerosol foam (mousse) (4). Ingredients in setting lotions that may affect reproduction are solvents and plasticizers $(4,6,12,13)$. Hair sprays have been widely used in the form of aerosol sprays, but have been partly replaced by nonaerosol sprays. The ingredients in the latter are generally the same as those in aerosol products, but the propellant content is replaced by additional solvents. The main route of absorption of these products is inhalation (4).

Ethanol is the most important solvent in the hair sprays that may cause reproductive disorders. Setting lotions contain up to $50 \%$ ethanol (4). In hair spray half of the content is solvent. The aerosol is highly respirable $(10,33)$. A case-referent study by Roeleveld et al (21) showed an increased risk of mental retardation after maternal occupational exposure to alcohol (21), but other studies describing an effect of occupational exposure to alcohol on reproduction have not been found. However, chronic alcohol consumption during pregnancy is known to cause several malformations and is the most frequent cause of mental deficiency in offspring (6). The adverse effects of alcohol in pregnancy, including the fetal alcohol syndrome (FAS), have been reviewed by Barrison et al (34). Effects such as perinatal mortality, premature placental separation, stillbirth, low birthweight, and mental retardation may be related to lower concentrations of alcohol $(6,12,21,34,35)$. However, little is known about exposure levels of ethanol in hairdressing salons. Preliminary results of a study on exposure to solvents in 18 hairdressing salons in The Netherlands have shown ethanol concentrations ( 8 -h time-weighted average) ranging from 0.1 to $56.6 \mathrm{mg} \cdot \mathrm{m}^{-3}$ (manuscript in preparation). As consumption of one alcoholic drink per day (approximately $17 \mathrm{~g}$ of alcohol) is considered to be harmless based on current knowledge $(21,36)$, inhalation of the aforementioned concentrations is not likely to cause reproductive disorders.

Acetone is another component of hairspray. A major problem in human studies on solvents, such as acetone, is that in most instances women are exposed to a mixture of solvents $(6,13)$. In a study on 782 women employed in laboratory work at the University of Göteborg (37), a slight increase in the spontaneous abortion rate was found for the group exposed to organic solvents, but the rate for pregnancies with acetone exposure was not higher than expected. No differences in perinatal death rates or in the prevalence of malformations were found between infants of exposed and unexposed mothers. According to a report of the Commission of European Communities (13), Nizyaeva performed a study among female factory workers who were chronically exposed to acetone at levels around $85 \mathrm{ppm}$ while producing acetate fibers. The problems found included increased threat of abortion, toxicosis and reduced birthweight. Animal studies on the reproductive effects of acetone did not show adverse effects up to exposure levels of $2200 \mathrm{ppm}$ (13). Preliminary results from the Dutch exposure study showed negligible concentrations of acetone in hairdressing salons (8-h time-weighted average $0.03-0.20 \mathrm{mg} \cdot \mathrm{m}^{-3}$ ) 
(manuscript in preparation). These concentrations are unlikely to cause adverse effects on reproduction.

Other solvents in hair-styling products are dichloromethane and 1,1,1-trichloroethane. These solvents have been widely used for many years, but recently they have been replaced by other solvents in some countries because of their toxicologic properties (4, personal communication from manufacturers). Concentrations of dichloromethane in the air of beauty salons were 1 4 ppm (38) and 6 ppm (39) (8-h time-weighted averages). The average exposure to dichloromethane while spraying was $18 \mathrm{ppm}$ in the breathing zone (39). Peak exposure concentrations of up to 400 ppm were measured as well (39). The use of adhesive sprays containing dichloromethane has been related to chromosome damage (40) and congenital malformations (41); however the evidence is equivocal (42). In a Finnish case-referent study on occupation and spontaneous abortions, the frequency of exposure to dichloromethane (and other solvents) was higher for cases than for referents (11 of 38 and 17 of 119, respectively) (43). In another Finnish study, an association between exposure to organic solvents (including dichloromethane) and central nervous system defects in offspring was found initially, but later disappeared, probably due to the decline in exposure to solvents (44). For animals there is some evidence of an increase in anomalies and postnatal behavioral changes (45). Carbon monoxide is a metabolite of dichloromethane. Prenatal exposure to high levels of carbon monoxide can result in fetal and infant death and in severe fetal brain damage (45).

A series of studies on adverse pregnancy outcomes was performed in a population that had received drinking water from a well accidentally contaminated with 1,1,1trichloroethane in California (46). An excess of major cardiac malformations was seen in children born to residents of this area, but this finding was contradicted by other studies (47). Animal studies do not suggest any significant reproductive toxicity from 1,1,1-trichloroethane (13).

Several epidemiologic studies on occupation and pregnancy outcome found increased risks of spontaneous abortions for women exposed to solvents in general (48-50). Other reproductive effects associated with exposure to mixtures of solvents include menstrual disorders (51), stillbirth $(49,52,53)$, preterm delivery (53), congenital malformations of the central nervous system (54), and congenital malformations in general (55).

A plasticizer in hairspray with possible reproductive effects is dibutylphthalate (13). No human data on this specific agent are available. Increased risk of spontaneous abortion was reported among women manufacturing phthalate chemicals (6). Embryofetal toxic effects of high doses of dibutylphthalate were observed in rats and mice (13). Dibutylphthalate may also be detrimental to the reproduction of some aquatic organisms at low concentrations (12).

Glycol ethers are used as dispersion improvers and perfumes. Studies among women in the electronics industry suggest that glycol ethers may cause an increased risk of spontaneous abortion $(56,57)$ and infants with a low birthweight (58). However, in these studies, quantifiable exposure data on glycol ethers and other chemicals were not available. In animals, ethylene glycol monomethyl ether has been shown to have the potential to induce reproductive toxicity in that the effects on fertility and the teratogenic potential of relatively large doses of these vapors were observed $(12,59)$.

\section{Other exposures}

Nitrosamines have been found in hair dyes, shampoos, rinses, and conditioners. The most common nitrosamine found is $\mathrm{N}$-nitrosodiethanolamine. In $1986,40 \%$ of samples of cosmetics and shampoos in Germany were contaminated with nitrosamines. Concentrations up to $275 \mu \mathrm{g} \cdot \mathrm{kg}^{-1}$ were found. Official recommendations to stop the use of secondary amines in cosmetics led to a reduction of such contamination; only $15 \%$ of the products were contaminated in a survey in Germany between 1987-1988 (4). Nitrosamines may be absorbed through human skin. According to in vivo penetration studies on monkeys and swine, about $18 \%$ of applied $\mathrm{N}$-nitrosodiethanolamine penetrates the skin (16). Epidemiologic studies have indicated nitroso compounds as possible causative agents for human childhood cancers, including those of neurogenic origin $(60-62)$.

Formaldehyde is added to many cosmetic products, particularly shampoos, as an antibacterial agent and preservative. It is also used in processes for hair setting or can be formed as a degradation product of materials containing polyethylene glycol. Concentrations of formaldehyde up to $0.03 \%$ have been found in shampoos, and up to $0.41 \%$ in hair rinse (4). Formaldehyde is known to penetrate the skin and is readily inhaled (6). Formaldehyde may cause menstrual disorders $(6,45)$, increased spontaneous abortion (6), and decreased fetal growth (45). John et al (63) found an elevated risk of spontaneous abortion for cosmetologists who use formaldehyde-based disinfectants. To our knowledge, formaldehyde concentrations in hairdressing salons have not been described, but they are expected to be low.

Hexachlorophene is also used as a disinfectant. A cluster of infants with malformations was observed among Swedish female hospital employees who frequently worked with the chemical during their pregnancies in 1978 (64). A causal association was quickly refuted by Källén (65). Another study showed no association between frequent exposure to hexachlorophene and the occurrence of perinatal deaths and malformations 
(66). Janerich (67) concluded that it had not yet been reasonably established whether or not hexachlorophene had teratogenic potential. Recently, Roeleveld et al (21) reported an increased risk of mental retardation for offspring of mothers exposed to hexachlorophene.

\section{Reproductive effects by occupation}

Epidemiologic studies on reproductive disorders among hairdressers appear to be scarce. To our knowledge only two studies have focused specifically on hairdressers $(63,68)$. In addition, several studies related pregnancy outcomes to maternal occupation in general and reported findings for hairdressers. The two specific studies and the most relevant explorative studies that included hairdressers are summarized in table 1 .

Blatter et al (68) compared the prevalence of menstrual disorders among hairdressers with the prevalence in a reference population of female shop assistants selling clothes in The Netherlands. A postal questionnaire was sent to 1200 hairdressers and 1200 shop assistants $20-45$ years of age, but only 64 hairdressers and 130 shop assistants could be used in the analysis because of nonresponse ( $40 \%$ for hairdressers, $46 \%$ for shop assistants) and the use of oral contraceptives (90\% for hairdressers, $77 \%$ for shop assistants). Statistically signifi- cant associations were found for irregular cycles, oligomenorrhea, unusual cycle length, long-lasting blood loss, and heavy and prolonged pains with odds ratios ranging from 2.4 to 9.4 .

Recently, the relation between spontaneous abortion and work in cosmetology during pregnancy was examined by John et al (63). A postal survey was conducted in North Carolina among 8356 licensed female cosmetologists $22-36$ years of age. Pregnancies were identified by a brief screening questionnaire (response rate $74 \%$ ), followed by a detailed postal questionnaire (response rate $74 \%$ ). The analyses were restricted to 96 cosmetologists with a spontaneous abortion and 547 cosmetologists with a single live birth. The women worked fulltime in cosmetology or in other jobs during the first trimester of pregnancy. The odds ratio for cosmetologists who worked more than $35 \mathrm{~h}$ a week was $1.4(0.8$ 2.3 ), and associations were found between spontaneous abortions and the number of chemical services performed per week. Elevated odds ratios were found for cosmetologists who performed more than two bleaches per week (OR 1.9, 95\% CI $1.0-3.7$ ), more than 10 permanents per week (OR 1.9, 95\% CI 1.0-3.6), and for the use of formaldehyde-based disinfectants (OR 1.7, 95\% CI 1.03.0). No associations were found for cosmetologists who worked less than $35 \mathrm{~h}$ a week or for cosmetologists who worked full-time but performed few chemical services (63).

Table 1. Studies reporting on reproductive risks among hairdressers. $(O R=$ adjusted odds ratio with $95 \%$ confidence interval in parentheses, $\mathrm{RR}=$ relative risk with $95 \%$ confidence interval in parentheses, $0: E$ ratio = observed: expected ratio, $N_{1}=$ number of outcomes, $\mathrm{N}_{2}=$ number of hairdressers with outcomes)

\begin{tabular}{|c|c|c|c|c|c|c|c|c|}
\hline Authors & Country & Study period & Study type & Source population & Outcomes studied & Results for hairdressers & $N_{1}$ & $\mathrm{~N}_{2}$ \\
\hline John et al (63) & United States & $1983-88$ & $\begin{array}{l}\text { Nested case- } \\
\text { referent }\end{array}$ & $\begin{array}{l}\text { Licensed } \\
\text { cosmetologists }\end{array}$ & Spontaneous abortion & OR $1.4(0.8-2.3)$ & 96 & 69 \\
\hline Blatter et al $(68,84)$ & The Netherlands & 1990 & Survey & $\begin{array}{l}\text { Hairdressers and } \\
\text { shop assistents }\end{array}$ & $\begin{array}{l}\text { Amenorrhoea } \\
\text { Irregular cycles } \\
\text { Oligomenorrhea } \\
\text { Unusual cycle length } \\
\text { Long blood loss } \\
\text { Severe pains } \\
\text { Long pains }\end{array}$ & $\begin{array}{l}\text { OR } 6.5(0.9-47.6) \\
\text { OR } 2.4(1.1-5.2) \\
\text { OR } 3.0(1.1-8.4) \\
\text { OR } 3.4(1.5-7.8) \\
\text { OR } 5.1(1.7-75.4) \\
\text { OR } 2.6(1.2-5.9) \\
\text { OR } 9.4(1.5-59.5)\end{array}$ & $\begin{array}{r}4 \\
56 \\
22 \\
63 \\
22 \\
116 \\
5\end{array}$ & $\begin{array}{r}3 \\
21 \\
10 \\
25 \\
12 \\
42 \\
4\end{array}$ \\
\hline Peters et al (69) & United Kingdom & 1958 & Survey & Deliveries & Major malformations & $0:$ E ratio 2.0 & 457 & 10 \\
\hline Roeleveld et al (21) & The Netherlands & $1979-87$ & Case referent & $\begin{array}{l}\text { Mental retardation, } \\
\text { referents }\end{array}$ & Mental retardation & $\begin{array}{l}O R_{\text {moanths } 1,2} 4.1\left(1.1-15.8^{\mathrm{a}}\right) \\
\mathrm{OR}_{\text {monnths } 3-6} 4.3\left(1.4-16.7^{\mathrm{a}}\right) \\
\mathrm{OR}_{\text {mononths } 6-8} 2.7\left(0.6-11.5^{\mathrm{a}}\right)\end{array}$ & $\begin{array}{l}139 \\
130 \\
106\end{array}$ & $\begin{array}{l}7 \\
7 \\
4\end{array}$ \\
\hline Shilling \& Lalich (70) & United States & 1980 & Survey & Deliveries & $\begin{array}{l}\text { Stillbirth (> } 28 \text { weeks) } \\
\text { Low birthweight } \\
\text { Congenital defects }\end{array}$ & $\begin{array}{l}0: \text { E ratio } 1.6 / 1.7 \\
0: \text { E ratio } 2.5 / 1.7 \\
\text { O:E ratio } 1.9 / 1.7\end{array}$ & $\begin{array}{r}3585 \\
1104 \\
470\end{array}$ & $\begin{array}{r}36 \\
18 \\
5\end{array}$ \\
\hline Vaughan et al (71) & United States & $1980-81$ & Survey & Birth records & Fetal death & RR $1.4(1.2-1.7)$ & 943 & 159 \\
\hline Kuijten et al (72) & The Netherlands & $1980-86$ & Case-referent & $\begin{array}{l}\text { Astrocytoma, } \\
\text { matched referents }\end{array}$ & Astrocytoma & $\begin{array}{l}\mathrm{OR}_{\text {preconcept }} 2.5(0.4-26.2) \\
\mathrm{OR}_{\text {pregnanay }} 1.5(0.2-18.0) \\
\mathrm{OR}_{\text {postnatal }} 3.0(0.2-157.7)\end{array}$ & 163 & $\begin{array}{l}5 / 2^{\mathrm{b}} \\
3 / 2^{\mathrm{b}} \\
3 / 1^{\mathrm{b}}\end{array}$ \\
\hline $\begin{array}{l}\text { Mc Donald et al } \\
(49,73-75)\end{array}$ & Canada & $1982-84$ & Survey & Deliveries & $\begin{array}{l}\text { Fetal death }(<28 \text { wks) } \\
\text { Stillbirth }(>28 \text { wks) } \\
\text { Low birthweight } \\
\text { Congenital defects }\end{array}$ & $\begin{array}{l}0: E \text { ratio } 1.02 \\
0: \text { E ratio } 0.43 \\
O: \text { E ratio } 1.08 \\
0: E \text { ratio } 0.51\end{array}$ & $\begin{array}{r}6746^{c} \\
294^{c} \\
2468^{c} \\
1427^{c}\end{array}$ & $\begin{array}{r}106^{c} \\
2^{c} \\
43^{c} \\
11^{c}\end{array}$ \\
\hline $\begin{array}{l}\text { Goulet \& Theriault } \\
\text { (52) }\end{array}$ & Canada & 1986 & Case-referent & $\begin{array}{l}\text { Fetal deaths, } \\
\text { matched referents }\end{array}$ & $\begin{array}{l}\text { Fetal death }(20-28 \text { wks }) \\
\text { Stillbitth }(>28 \text { wks })\end{array}$ & $\begin{array}{l}\text { OR } 0.3(0.1-1.7) \\
\text { OR } 0.1(0.0-1.4)\end{array}$ & $\begin{array}{l}124 \\
103\end{array}$ & $\begin{array}{l}2 / 6^{b} \\
1 / 6^{b}\end{array}$ \\
\hline
\end{tabular}

$90 \%$ confidence interval.

b Number of exposed (hairdressers) cases/referents in the discordant pairs.

c See reference 74 . 
In the British perinatal mortality survey (1958), twice as many perinatal deaths as expected from congenital malformations were found among hairdressers. However, the number of perinatal deaths from congenital malformations among hairdressers was small $(\mathrm{N}=10)$, and exposure assessment was based on job titles only (69).

The possible association between maternal occupational exposure and mental retardation in offspring was explored in a case-referent study among 306 mentally retarded children with an unknown etiology (cases) and 322 physically handicapped children (referents) (21). Data were collected in personal interviews, and chemical exposure was assessed according to industry-specific checklists. Statistically significantly increased odds ratios were found for hairdressers working in the first or second month of pregnancy and in the third through the fifth months of pregnancy. This odds ratio was still increased, although not statistically significantly, for women who worked in late pregnancy. Elevated odds ratios were also found for exposure to hair cosmetics or dyes (OR 3.7, 90\% CI 0.9-15.1), alcohol (OR 1.9, 90\% CI $1.0-2.5$ ), hexachlorophene or phenylphenol (OR 3.1, $90 \%$ CI 1.0-9.7), and other disinfectants (OR 1.5, 90\% CI $0.8-2.8$ ).

Data from the 1980 national natality and national fetal mortality surveys in the United States were used to investigate maternal occupation during the year before delivery in relation to pregnancy outcome (70). This study included 70 live births among women working in beauty parlors and barber shops. A nonsignificant increase in the prevalence of infants with low birthweights was noted (prevalence $2.5 \%$ ). No increase was found in the prevalence of malformations $(1.9 \%)$ and fetal deaths (1.6\%) among the offspring of hairdressers.

Using 130000 birth records collected by the State of Washington (in the United States) in 1980 and 1981, Vaughan et al (71) noted a small excess of fetal deaths among hairdressers.

Kuijten et al (72) performed a case-referent study on parental occupation and childhood astrocytoma. Interviews were conducted with both parents of 163 cases and 163 referents. Elevated, but not statistically significant odds ratios were observed for hairdressers exposed before, during, and after pregnancy.

McDonald et al (49, 73-75) performed a survey on several pregnancy outcomes and maternal occupation during pregnancy in Montreal (Canada). In this study, 56067 women were interviewed after delivery or spontaneous abortion about the outcome of the current and all previous pregnancies. The observed : expected ratio for spontaneous abortion $(49,73,74)$, stillbirth $(49,74)$, low birthweight of infants (74), and congenital defects of infants $(74,75)$ among hairdressers did not show an excess risk. In two of these analyses $(49,75)$, type and level of chemical exposures per job were estimated by an industrial hygienist. Only exposures exceeding $30 \%$ of the threshold limit value were included in the analysis. An elevated observed : expected ratio was found for stillbirths after exposure to solvents in a variety of jobs (49).

Using the same data base, Goulet \& Theriault (52) performed a case referent study on stillbirths and the chemical exposure of pregnant workers. They included 124 fetal deaths and 103 stillbirths without major malformations and 227 live births without major malformations. A decreased risk of stillbirth was found among hairdressers who worked more than $30 \mathrm{~h}$ a week, but the authors explained this negative association by the use of an improper reference group. In this study chemical exposure profiles developed by McDonald et al (75) were used to estimate the chemical exposure. The study suggested that exposure to metals and solvents could increase the risk of stillbirth (52).

In an analysis of all naturally terminated pregnancies $(\mathrm{N}=6166)$ in the district of Gottwaldov in Czechoslovakia in 1981-1983, an increased ratio of reproductive losses was reported for hairdressers (76). In a casereferent study on neural tube defects in Venezuela, Hammond \& Canache (77) found that $13.6 \%$ of the mothers of the cases $(\mathrm{N}=76)$ were hairdressers but only $1.3 \%$ of the mothers of the referents were hairdressers.

Two other studies did not specifically address hairdressers, but they provide results for agents that are used in the hairdressing trade. Decouflé et al (78) performed a case-referent study on mental retardation and mothers' employment during pregnancy in Atlanta (United States). Mothers of 352 case children and 408 reference children were interviewed with an extensive questionnaire. They found a possible positive relationship between mental retardation and mothers' self-reported occupational exposure to miscellaneous kinds of chemical products such as ammonia and spray adhesives (78). Tikkanen et al (79) studied associations between occupational factors and cardiovascular malformations for the period 1980 1981 using the Finnish Register of Congenital Malformations. No difference was reported between 160 cases and 160 referents for "substantial exposure to hairdresser's chemicals" (79).

\section{Discussion}

This review explores possible reproductive effects of the agents used by hairdressers. However, human studies appeared to be scarce. For several agents (selenium, some dye formulations, dibutylphthalate, ethylene glycol ethers, methoxy ethanol, lead acetate) reproductive toxicity was reported for animals, whereas no or few human data were available. It is difficult to extrapolate these 
results to hairdressers. In animal studies relatively large doses are administered, whereas the concentrations of these agents in the hairdressing salon are relatively low. In addition the amount of absorption may be different between animals and humans and the route of exposure is often not comparable with the situation in the hairdressing salon. Nevertheless, the results of experimental animal studies may provide an indication for the possible risk of reproductive disorders among hairdressers. Furthermore, hairdressers are exposed to a mixture of agents, and such exposure is typical for this occupation. The effect of this combined exposure on reproduction is hard to assess. It has been shown that contact with permanentwave solutions facilitates the absorption of other agents through the skin (9).

Reproductive disorders in humans were described in relation with exposure to solvents, nitrosamines, formaldehyde, and hexachlorophene. There is evidence that solvents may adversely affect reproductive outcomes and they are probably the most important agents in the hairdressing salon. Solvents occur in a relatively high concentration $(50 \%)$ in hairstyling products, which are frequently used in hairdressing salons, and in lower concentrations in permanents and dyes as well. Currently the most important solvent for reproductive disorders in the hairdressing salon might be ethanol. Although alcohol consumption is known to cause adverse reproductive effects, no studies were found which focused on occupational exposure to ethanol, and no data were found on the relevance of occupational exposure to ethanol next to alcohol consumption. According to unpublished measurements in The Netherlands and the amount of absorption through inhalation $( \pm 70 \%)$, ethanol exposure levels among hairdressers will lead to very low blood concentrations compared with alcohol consumption. Although the reproductive effects of chronic low exposure to ethanol are unknown, these concentrations might be too low to constitute a reproductive risk $(34,36)$. There is evidence for reproductive risks of dichloromethane, but this agent is used less in hair products nowadays because of its toxicologic properties (4). The majority of human studies did not demonstrate specific effects linked to specific solvents. This result suggests a general (structure nonrelated) effect of this class of chemicals (5), but others state that chronic toxicity of solvents, such as teratogenicity, is related to a given chemical structure (structure-related toxicity) $(12,59)$. The actual reproductive risk of nitrosamines, formaldehyde, and hexachlorophene is not clear, and, although these agents occur in several products, exposure levels will be low.

The associations of the number of performed bleaches and permanents per week with an increased risk of spontaneous abortion as reported by John et al (63) are not supported by the literature concerning the components of these products. In both activities exposure to hydrogen peroxide takes place, but no human data are available for hydrogen peroxide and no adverse reproductive effects on animals were described.

It is difficult to evaluate the evidence for the reproductive toxicity of hair dyes, which contain several potential teratogenic agents, because of the lack of human data and inconsistent results in animal studies. Maternal use of hair dyes has been related to increased risks of childhood cancer $(19,20)$, and several dye substances have been found to be mutagenic (4) and to be absorbed through the skin $(16,17)$ and placenta $(80)$. These findings might indicate that occupational exposure to hair dyes is a risk factor for childhood cancers. However, duration of exposure and the amount of absorption of dyestuffs (16) might be different between personal use of hair dyes and occupational exposure to hair dyes. The latter is affected by the method of dye application and the use of protective gloves. Most hairdressers wear gloves when dyeing, according to the studies of Zielhuis \& Blatter (81) (55\% always and $16 \%$ most of the time) and John (82) (64\% always and $21 \%$ most of the time). However, Peculia et al (83) estimated that only one-third of hairdressers currently use protective gloves when dyeing hair. Furthermore, the amount of absorption strongly depends on the duration of dermal contact (16). Therefore, the possibility of a reproductive risk of hair dyes might be strongly affected by the way the hair dyes are handled.

The two epidemiologic studies focusing on hairdressers have found adverse effects on menstrual function (68) and on the rate of spontaneous abortion (63). However, in the study on menstrual disorders nondifferential selection due to differences in oral contraceptive use cannot be excluded. Nonetheless, these studies lend support for a reproductive risk at current exposure levels. In other, more explorative epidemiologic studies, the findings on the association between the chemical exposure of hairdressers and reproductive disorders are inconsistent, probably due to insufficient numbers of hairdressers in the study populations to be able to detect specific effects of occupational exposures of hairdressers.

Moreover, in most of the reported studies, exposure assessment was based on job title. Given the large proportion of hairdressers who work part-time and the variation in number and types of services provided, job title alone is a poor surrogate measure for chemical exposures. Therefore, using job title may dilute any true association between occupational exposures in cosmetology and adverse reproductive outcomes (63). The study of John et al (63) only identified increased risks of spontaneous abortion when specific work activities and intensive exposure levels were considered. Shaw et al (84) reported that only for $71 \%$ of the mothers the occupation on the birth certificate was the same as the occupation 
elicited from the interview, so that all but very strong associations would be missed. Another problem with studies using job titles is that no distinction can be made between chemical influences and the effects of physical work load on reproduction (85). John et al (63) found an odds ratio of $1.9(95 \%$ CI $1.0-3.9)$ for hairdressers who reported standing for $\geq 9 \mathrm{~h}$ a day. Thus, if interested in chemical exposures in relation to reproductive disorders, prolonged standing might be an unmeasured confounding variable when job titles are used as a proxy for exposure. Several studies $(52,73,74,78)$ also controlled for socioeconomic status, and this practice could have led to overadjustment when occupational factors were evaluated. Adverse effects may be obscured if differences in socioeconomic status are caused by the distribution of occupations associated with reproductive outcomes among cases and referents.

Although toxicologic considerations do play an increasingly important role in product formulation, reproductive risks are usually not taken into account. However, officials in some countries have recently banned or limited the use of specific agents (eg, some dye formulations, dichloromethane, selenium disulfide, nitrosamines, lead acetate) (4). For these and other reasons the chemical environment in hairdressing salons is changing, and therefore reproductive risks that were present in earlier years may (unintentionally) decrease or disappear.

Inconsistent results of epidemiologic studies and the limited human data on the reproductive risks of chemicals and concentrations used in the hairdressing salon make the drawing of conclusions difficult. Reproductive risks cannot be excluded, but, to date, there is little evidence for reproductive risks at concentrations prevalent in hairdressing salons. Future research should examine the reproductive risks among hairdressers in more detail, as they constitute a major group of female workers with chemical exposures at child-bearing age. Since hairdressers are exposed to chemical mixtures from several products, exposure might be variable and hard to assess. Therefore, more attention should be paid to exposure assessment in future research. Moreover, such studies should not only focus on outcomes like fetal death, perinatal death, and congenital malformations, but also on more subtle outcomes such as time to pregnancy, birthweight, and functional development. These outcomes might be more sensitive to chemical exposures in pregnancy at concentrations expected to be prevalent in hairdressing salons.

\section{Acknowledgments}

This study was financially supported by The Netherlands Organization of Scientific Research.

\section{References}

1. Zviak C. The science of hair care. New York, Basel: Marcel Dekker Inc, 1986.

2. Heacock HJ, Rivers JK. Occupational diseases of hairdressers. Can J Public Health 1986;77:109-13.

3. Frosch PJ, Burrows D, Camarasa JG, Dooms-Goossens A, Ducombs $G$, Lahti A, et al. Allergic reactions to a hairdressers' series: results from 9 European centres. Contact Dermatitis $1993 ; 28: 180-3$.

4. International Agency for Research on Cancer (IARC). Occupational exposures of hairdressers and barbers and personal use of hair colourants; some hair dyes, cosmetic colourants, industrial dyestuffs and aromatic amines. Lyon: IARC, 1993. IARC monographs on the evaluation of carcinogenic risks to humans, vol 57.

5. Zielhuis RL, Stijkel A. Adverse effects of organic solvents on fertility and reproduction; a critical review. Zeist: TNO-CIVO Toxicology and Nutrition Institute, 1988.

6. Schardein JL. Chemically induced birth defects. New York, Basel: Marcel Dekker Inc, 1985.

7. Rosenberg MJ, Feldblum PJ, Marshall EG. Occupational influences on reproduction: a review of recent literature. J Occup Med 1987;29:584-91.

8. Shaw GM, Gold EB. Methodological considerations in the study of parental occupational exposures and congenital malformations in offspring. Scand J Work Environ Health 1988; $14: 344-55$.

9. Annema JA. Mooi is anders [Not that beautiful]. Utrecht (The Netherlands): Stichting Natuur en Milieu, 1988.

10. Marquart J. Chemische stoffen in de lucht van kapsalons: inventarisatie van belastende factoren bij en mogelijke schadelijke effecten van het werk van kappers en kapsters [Chemicals in the air of hairdressing salons: an inventory]. Rijswijk (The Netherlands): Medisch Biologisch Laboratorium TNO, 1988.

11. Dahl S. Gesundheitsprobleme bei der friseurarbeit. Esbjerg (Denmark): Central Hospital in Esbjerg and University Centre of South Nutlano, 1990. English summary,

12. Amdur MD, Doull J, editors. Casaret and Doull's toxicology: the basic science of poisons. New York (NY): Pergamon Press, 1993.

13. Commission of the European Communities. Reproductive toxicity: the toxicology of chemicals series two. Luxembourg, Edinburgh: Office for Official Publications of the European Communities, 1993.

14. Iyer G, Kannan K, Khan RR. Toxicology of hairdyes: an overview. J Sci Ind Res 1985;44:392-402.

15. Babish JG, Scarlett JM, Voekler SE, Gutenmann WH, Lisk DJ. Urinary mutagens in cosmetologists and dental personnel. J Toxicol Environ Health 1991;34:197--206.

16. Marzulli FN, Anjo DM, Maibach HI. In vivo skin penetration studies of 2,4-toluenediamine, 2,4-diaminoanisole, 2-nitro-pphenylenediamine, $\mathrm{p}$-dioxane and $\mathrm{n}$-nitrosodiethanolamine in cosmetics. Food Cosmet Toxicol 1981;19:743-7.

17. Wolfram LJ, Maibach HI. Percutaneous penetration of hair dyes. Arch Dermatol Res 1985;277:235-41.

18. Gagliardi L, Ambroso M, Mavro J, Furno F, Discalzi G. Exposure to paraphenylendiamine in hairdressing parlors. Int J Cosmet Sci 1992;14:19-31.

19. Bunin GR, Kramer S, Marrero O, Meadows AT. Gestational risk factors for Wilms' tumor: results of a case-control study. Cancer Res 1987;47:2972-7.

20. Kramer S, Ward E, Meadows AT, Malone KE. Medical and 
drug risk factors associated with neuroblastoma: a case-control study. JNCI 1987;78:797—804.

21. Roeleveld N. Mental retardation and parental occupation: an explorative epidemiologic study [dissertation]. Nijmegen (The Netherlands): University of Nijmegen, 1991.

22. Inouye $M$, Murakami U. Teratogenicity of 2,5-diaminotoluene, a hair dye constituent, in mice. Food Cosmet Toxicol 1977;15:447-51

23. Marks TA, Gupta BN, Ledoux TA, Staples RE. Teratogenic evaluation of 2-nitro-p-phenylenediamine, 4-nitro-o-phenylenediamine, and 2,5-toluenediamine sulfate in the mouse. Teratology $1981 ; 24: 253-65$.

24. Burnett C, Goldenthal EI, Harris SB, Wazeter FX, Strausburg J, Kapp R, et al. Teratology and percutaneous toxicity studies on hair dyes. J Toxicol Environ Health 1976;1:1027—40.

25. Burnett $\mathrm{CM}$, Goldenthal EJ. Multigeneration reproduction and carcinogenicity studies in Sprague-Dawley rats exposed topically to oxidative hair-colouring formulations containing pphenylenediamine and other aromatic amines. Food Chem Toxicol 1988;26:467-74

26. Wernick T, Lanman BM, Fraux JL. Chronic toxicity, teratologic, and reproduction studies with hair dyes. Toxicol Appl Pharmacol 1975;32:450-60.

27. Addendum to the final report on the safety assessment of hydroquinone. J Am Coll Toxicol 1994;13:167-230.

28. Final report on the safety assessment of Pyrogallol. J Am Coll Toxicol 1991;10:67-85.

29. Final report on the safety assessment of p-aminophenol, maminophenol, and o-aminophenol. J Am Coll Toxicol 1988; 7:279-333.

30. Eiche A, Bexell G, Sandelin K. Genotoxicity of p-aminophenol in somatic germ line cells of Drosphila melanogaster. Mutat Res 1990;240:87-92.

31. Cohen AJ, Roe FJC. Review of lead toxicity relevant to the safety assessment of lead acetate as a hair colouring. Food Chem Toxicol 1991;29:485-507.

32. Clausen T. Hair colouring preparations. In: Elvers B, Hawkins S, Ravenscroft M, Rounsaville JF, Schulz G, editors. Ullmann's encyclopedia of industrial chemistry. New York (NY): VCH Publishers, 1989:583-8.

33. Draize JH, Nelson AA, Newburger SH, Kelley EA. Inhalation toxicity studies of six types of aerosol hair sprays. Proc Sci Sect Toilet Goods Assoc 1959;31:28 - 32.

34. Barrison IG, Waterson EJ, Murray-Lyon IM. Medical reviews series 4: adverse effects of alcohol in pregnancy. $\mathrm{Br} \mathrm{J}$ Addict 1985;80:11-22.

35. Little RE, Asker RL, Sampson PD, Renwick JH. Fetal growth and moderate drinking in early pregnancy. Am J Epidemiol 1986;123:270-8.

36. Verkerk PH, Zaadstra BM, Reerink JD, Herngreen WP, Verloove-Vanhorick SP. Social class, ethnicity, and other risk factors for small for gestational age and preterm delivery in the Netherlands. Eur J Obstet Gynecol Reprod Biol 1994;53: $129-34$.

37. Axelsson G, Lutz C, Rylander R. Exposure to solvents and outcome of pregnancy in university laboratory employees. $\mathrm{Br}$ J Ind Med 1984;41:305-12.

38. Gerkens R, Zucchini G, Ambroso M. MethylenchloridKonzentration in Friseursalons. Aerosol Report 1989;28: $121-9$.

39. Sayad RS, Stevenson MP, Skory LK, Jordan JW. Methylene chloride in hair sprays. Soap Cosmet Chem Spec 1971;52:8790, 134-6.

40. Possible link to chromosomal gaps leads to ban on spray adhesives [medical news]. JAMA 1973;13:1581-2.

41. Silberg SL, Ransom DR, Lyon JA, Anderson PS. Relationship between spray adhesives and congenital malformations. South Med J 1979;72:1170-3.

42. Hanson JW, Oakley G. Spray adhesives and birth defects. JAMA 1976;236:1010.

43. Taskinen H, Lindbohm M, Hemminki K. Spontaneous abortions among women working in the pharmaceutical industry. Br J Ind Med 1986;43:199-205.

44. Kurppa K, Holmberg PC, Hernberg S, Rantala K, Riala R, Nurminen T. Screening for occupational exposures and congenital malformations: preliminary results from a nationwide case-referent study. Scand J Work Environ Health 1983;9: 89-93.

45. Barlow SM, Sullivan FM. Reproductive hazards of industrial chemicals: an evaluation of animal and human data. London: Academic Press, 1982.

46. Deane M, Swan SH, Harris JA, Epstein DM, Neutra RR. Adverse pregnancy outcomes in relation to water contamination, Santa Clara County, California, 1980-1981. Am J Epidemiol 1989;129:894-904.

47. Wrensch M, Swan S, Lipscomb J, Epstein D, Fenster L, Claxton K, et al. Pregnancy outcomes in women potentially exposed to solvent-contaminated drinking water in San Jose, California. Am J Epidemiol 1990;131:283-300.

48. Lindbohm M, Taskinen H, Sallmen BA, Hemminki K. Spontaneous abortions among women exposed to organic solvents. Am J Ind Med 1990;17:449—63.

49. McDonald AD, McDonald JC, Armstrong B, Cherry NM, Cote R, Lavoie J, et al. Fetal death and work in pregnancy. Br J Ind Med 1988;45:148-57.

50. Windham GC, Shusterman D, Swan SH, Fenster L, Eskenazi B. Exposure to organic solvents and adverse pregnancy outcome. Am J Ind Med 1991;20:241 - 59.

51. Lemasters GK, Hagen A, Samuels SJ. Reproductive outcomes in women exposed to solvents in 36 reinforced plastics companies. J Occup Med 1985;27:490—4.

52. Goulet L, Thériault G. Stillbirth and chemical exposure of pregnant workers. Scand J Work Environ Health 1991;17:2531.

53. Savitz DA, Whelan EA, Kleckner RC. Effect of parents' occupational exposures on risk of stillbirth, preterm delivery, and small for gestational age infants. Am J Epidemiol 1989;129:1201-18.

54. Holmberg PC, Nurminen N. Congenital defects of the central nervous system and ocupational factors during pregnancy: a case-referent study. Am J Ind Med 1980;1:167-76.

55. Cordier S, Ha M-C, Ayme S, Goujard J. Maternal occupational exposure and congenital malformations. Scand $J$ Work Environ Health 1992;18:11-7.

56. Pastides H, Calabrese EJ, Hosmer DW, Harris DR. Spontaneous abortion and general illness symptoms among semiconductor manufacturers. J Occup Med 1988;30:543—51.

57. Huel G, Mergler D, Bowler R. Evidence for adverse reproductive outcomes among microelectronic assembly workers. $\mathrm{Br} \mathrm{J}$ Ind Med 1990;47:400-4.

58. Lipscomb JA, Fenster L, Wrensch M, Shusterman D, Swan S Pregnancy outcomes in women potentially exposed to occupational solvents and women working in the electronics industry. J Occup Med 1991;33:597-604.

59. Ikeda I. Public health problems of organic solvents. Toxicol Lett 1992;64-65:191-201.

60. Anderson LM, Hagiwara A, Kovatch RM, Rehm S, Rice JM. Transplacental initiation of liver, lung, neurogenic, and con- 
nective tissue tumors by n-nitroso compounds in mice. Fundam Appl Toxicol 1989;12:604-20.

61. Preston-Martin S, Correa P. Epidemiological evidence for the role of nitroso compounds in human cancer. Cancer Surv 1989;8:459-73.

62. Preston-Martin S, Yu MC, Benton B, Henderson BE. N-nitroso compounds and childhood brain tumors: a case control study. Cancer Res 1982;42:5240-5.

63. John EM, Savitz DA, Shy CM. Spontaneous abortions among cosmetologists. Epidemiology 1994;5:147—54.

64. Check W. New study shows hexachlorophene is teratogenic in humans. JAMA 1978;240:513-4.

65. Källén B. Hexachlorophene teratogenicity in humans disputed. JAMA 1978;240:1585-6.

66. Baltzar B, Ericson A, Kallen B. Pregnancy outcome among women working in Swedish hospitals [editorial]. N Engl J Med 1979;300:627-8.

67. Janerich DT. Environmental causes of birth defects: the hexachlorophene issue [editorial]. JAMA 1979;241:830-1.

68. Blatter BM, Zielhuis GA. Menstrual disorders due to chemical exposure among hairdressers. Occup Med 1993;43:105-6.

69. Peters TJ, Adelstein P, Golding J, Butler NR. The effects of work in pregnancy: short- and long-term associations. In: Chamberlain G, editor. Pregnant women at work. London: Royal Society of Medicine, 1984:87-104.

70. Shilling S, Lalich NR. Maternal occupation and industry and the pregnancy outcome of US married women, 1980. Public Health Rep 1984;99:152—61.

71. Vaughan TL, Daling JR, Starzyk PM. Fetal death and maternal occupation. J Occup Med 1984;26:676-8.

72. Kuijten RR, Bunin GR, Nass CC, Meadows AT. Parental occupation and childhood astrocytoma: results of a case-control study. Cancer Res 1992;52:782-6.

73. McDonald AD, Armstrong B, Cherry NM, Delorme C, Nolin $\mathrm{AD}, \mathrm{McDonald} \mathrm{JC}$, et al. Spontaneous abortion and occupation. J Occup Med 1986;28:1232-8.

74. McDonald AD, McDonald JC, Armstrong B, Cherry NM Delorme $\mathrm{C}$, Nolin $\mathrm{AD}$, et al. Occupation and pregnancy outcome. Br J Ind Med 1987;44:521-6.

75. McDonald AD, McDonald JC, Armstrong B, Cherry NM,
Cote R, Lavoie J, et al. Congenital defects and work in pregnancy. Br J Ind Med 1988;45:581-8.

76. Mares $\mathrm{P}$, Baran P. Occupation of pregnant women in relation to the course and outcome of pregnancy [in Czech]. Cs Gynekologie 1989;54:1—6.

77. Hammond FG, Canache de MG. Some epidemiological aspects of neural tube defects in Barquisimeto, Venezuela [abstract]. Am J Hum Genet 1991;49 suppl 470.

78. Decouflé P, Murphy C, Drews CD, Yeargin-Allsopp M. Mental retardation in ten-year-old children in relation to their mother's employment during pregnancy. Am J Ind Med 1993; $24: 567-86$

79. Tikkanen J, Kurppa K, Timonen H, Holmberg PC, Kuosma E, Rantala K. Cardiovascular malformations, work attendance, and occupational exposures during pregnancy in Finland. Am J Ind Med 1983;4:293- 307.

80. DiNardo JC, Picciano JC, Schnetzinger RW, Morris WE, Wolf BA. Teratological assessment of five oxidative hair dyes in the rat. Toxicol Appl Pharmacol 1985;78:163-6.

81. Zielhuis GA, Blatter BM. Het optreden van menstruatiestoornissen in relatie tot chemische blootstelling bij kapsters [Menstrual disorders due to chemical exposure among hairdressers]. Tydschrift Soc Gezondheidszorg 1992;70:374-81. English abstract.

82. John EM. Spontaneous abortions among cosmetologists [dissertation]. Chapel Hill (NC): University of North Carolina, 1990.

83. Pukkala E, Nokso-Koivisto P, Roponen P. Changing cancer risk pattern among Finnish hairdressers. Int Arch Occup Environ Health 1993;64:39-42.

84. Shaw GM, Malcoe LH, Croen LA, Smith DF. An assessment of error in parental occupation from the birth certificate. Am J Epidemiol 1990;131:1072 - 9.

85. Goulet $\mathrm{L}$, Thériault $\mathrm{G}$. Association between spontaneous abortion and ergonomic factors: a literature review of the epidemiologic evidence. Scand J Work Environ Health 1987;13:399403.

Received for publication: 12 December 1994 